Review / Artículo de revisión / Artigo de revisão - Tipo 3

\title{
Handover Algorithms in LTE Networks for Massive Means of Transport
}

\author{
Euler Adrián Trejo Narváez / etrejo@unicauca.edu.co \\ Claudia Milena Hernandez Bonilla / claudiah@unicauca.edu.co
}

Universidad del Cauca, Popayán-Colombia

ABSTRACT Handover in LTE occurs when a device moves from the cell coverage serving it towards another; a process where the user established session must not be interrupted due to this cell change. Handovers in LTE are classified as hard ones, since the link with the serving cell is interrupted before establishing the new link with the target cell. This entails a larger failure risk and, consequently, a potential deterioration in the quality of service. This article presents a review of the handover algorithms in LTE, focusing on the ones oriented to massive means of transport. We show how the new algorithms offer a larger success in handovers, increasing the networkdata rate. This indicates that factors such as speed, position, and direction should be included in the algorithms to improve the handover in means of transport. We also present the algorithms focused on mobile relays such as an important study field for future research works.

KEYWORDS Handover in LTE; massive means of transport; mobile femtocells; mobile relays.

\section{Algoritmos de traspaso de redes LTE en medios de transporte masivo}

RESUMEN El traspaso en LTE se presenta cuando un equipo pasa de la cobertura de una celda a la de otra, un proceso en el que se debe asegurar que el usuario no vea interrumpida su sesión, como efecto de ese cambio de celda. Los traspasos en LTE son del tipo duro, en ellos, el enlace con la celda servidora se interrumpe antes de establecer el nuevo enlace con la celda destino, lo que conlleva a un mayor riesgo de falla y con ello a un probable deterioro de la calidad del servicio al usuario. Este artículo revisa algoritmos de traspaso LTE, enfocándose en aquellos orientados a medios de trasporte masivo. Muestra cómo los nuevos algoritmos ofrecen una tasa mayor de traspasos exitosos y con ello una mejor tasa de transferencia de datos; evidencia que factores como la velocidad, la posición y la dirección deben ser incluidos en los algoritmos dirigidos a mejorar el traspaso en medios de transporte; y presenta a los algoritmos enfocados en relays móviles, como un importante campo de estudio para futuras investigaciones.

PALABRAS CLAVE Traspaso en LTE; relays móviles; femtoceldas móviles; medios de transporte masivo.
Algoritmos de transferência de redes LTE em meios de transporte massivo

RESUMO A transferência em LTE ocorre quando um dispositivo passa da cobertura de uma célula para outra, um processo no qual deve ser assegurado que o usuário não veja sua sessão interrompida, como resultado dessa mudança de célula. As transferências em LTE são do tipo duro, nelas, o link com a célula do servidor é interrompido antes de se estabelecer o novo link com a célula alvo, o que leva a um maior risco de falha e, portanto, a uma provável deterioração da qualidade do serviço ao usuário. Este artigo revisa os algoritmos de transferência LTE, com foco naqueles orientados a meios de transporte massivo. Mostra como os novos algoritmos oferecem uma taxa maior de transferências bem-sucedidas e, com isso, uma melhor taxa de transferência de dados; evidencia de que fatores como a velocidade, a posição e a direção devem ser incluídos nos algoritmos que visam melhorar a transferência nos meios de transporte; e apresenta os algoritmos focados em relés móveis, como um importante campo de estudo para futuras pesquisas.

PALAVRAS-CHAVE Transferência em LTE; relés móveis; femtocélulas móveis; meios de transporte massivo. 


\section{Introduction}

The growing trend in the mobile data traffic is mainly focused on the indoor traffic; hence, the small cell solutions (i.e., microcells, picocells, and femtocells) have arisen to handle this traffic and the deployment of diverse networks (3rd Generation Partnership Project - Technical Specification Group Radio Access Network [3GPP-TSGRAN], 2013; 3GPP TSGRAN, 2014b) are some of the aspects with larger interest and development nowadays (Holma, Toskala, \& Reunanen, 2016).

The massive means of transport are not isolated from that trend. Considering the large number of users in the public transportation and their high mobility within the cellular networks coverage, a large number of terminals or user equipment [UE] must execute handover processes between cells. This demands a high load to the control plane, increases the mobility signaling, and affects the successfully executed handovers rate.

Within LTE, the handover process is executed when a UE moves from the cell coverage serving it towards another. Hence, this process must ensure that the session the user has continues and does not suffer interruptions when the cell change is performed. Furthermore, all the handovers performed in LTE are from the hard type, that is, the link with the current cell is interrupted before establishing the new link with the target cell. This process generates a larger load to the control plane and entails that the handover process might present a higher failure risk. With the increase in the failed handovers, there is a direct increase in the Radio Bearers [RB] cuts established by the terminals, generating degradation in the signals and finally, impacting the service provided to the end users.

Currently, the mobile operators try to provide coverage in trains, subways, and large avenues with macro cells; but these cells do not provide the enough quality to maintain the performance indicators in acceptable thresholds. For this reason, these macro cells do not provide a good user experience in those places.

Considering the idea in the previous paragraph, the 3GPP-TSGRAN (2010) has worked in the technical report TR 36.806. Within it, four architectures for fixed relays have been defined, which consist of base stations (macro) allowing the signal retransmission from a donor cell [DeNB, DonoreNodeB] towards the UEs. Contrary to the repeaters, the relays have Forward Error Correction [FEG] capabilities and they can (or cannot) have a unique Physical Cell Identity [PCI].

After, the 3GPP-TSGRAN (2014a) worked in an evolution of their previous report (TR 36.836), where six archi-

\section{Introducción}

La tendencia de crecimiento para el tráfico de datos móviles se orienta principalmente al tráfico en interiores, por lo cual las soluciones de celdas pequeñas (i.e., microceldas, picoceldas y femtoceldas), enfocadas en el manejo de este tipo de tráfico, y el despliegue de redes heterogéneas (3rd Generation Partnership Project - Technical Specification Group Radio Access Network [3GPP-TSGRAN], 2013; 3GPP TSGRAN, 2014b) son algunos de los aspectos con mayor desarrollo en la actualidad (Holma, Toskala, \& Reunanen, 2016).

Los medios de transporte masivo no son ajenos a dicha tendencia. Teniendo en cuenta la gran cantidad de usuarios de transporte público y su alta movilidad dentro de la red de cobertura celular, una cantidad considerable de equipos terminales [UE, User Equipments] deben ejecutar procesos de traspaso entre celdas, lo que: exige una alta carga al plano de control, incrementa la señalización de movilidad y degrada la tasa de traspasos que se completan de manera exitosa.

En LTE el proceso de traspaso se realiza cuando un UE pasa de la cobertura de una celda a otra, por lo tanto, el proceso de traspaso debe asegurar que la sesión que mantiene el usuario no sea interrumpida al cambiar de celda. En LTE todos los traspasos que se realizan son del tipo duro, es decir, el enlace con la celda servidora se interrumpe antes de establecer el nuevo enlace con la celda destino, lo cual genera una mayor carga del plano de control y hace que el proceso de traspaso presente un mayor riesgo de fallas. Con el incremento de los traspasos fallidos se produce un incremento de cortes en los RB [Radio Bearers] establecidos por los equipos terminales, generando una degradación que finalmente impacta el servicio prestado a los usuarios.

Actualmente los operadores tratan de cubrir las vías de tren, las líneas de metro y las avenidas, con macro celdas, pero ellas no brindan la calidad suficiente para mantener los indicadores de desempeño dentro de umbrales aceptables y, por lo tanto, no proporcionan una buena experiencia al usuario.

Teniendo en cuenta lo anterior, el 3GPP-TSGRAN (2010) ha trabajado en el reporte técnico TR 36.806 y con él, definido cuatro arquitecturas para relays fijos, que son estaciones base (macro) que permiten retransmitir la señal de una estación donante [DeNB, Donore NodeB] hacia los equipos terminales.

A diferencia de los repetidores, los relays incorporan funciones de corrección de errores de transmisión [FEC, Forward Error Correction] y pueden o no poseer un identificador físico de celda [PCI, Physical Cell Identity] propio.

Posteriormente, el 3GPP-TSGRAN (2014a) trabajó en una evolución del anterior reporte, el TR 36.836, con el cual definió seis arquitecturas para relays móviles, con el propósito de sentar las bases para brindarle servicio a quienes utilizan trenes de alta velocidad, mediante la implementación de redes de retorno móviles inalámbricas. Los relays móviles son estaciones base implementadas sobre trenes de alta velocidad. El relay móvil se conecta de manera inalámbrica a una DeNB mediante una interfaz de radio $U n$. 
El relay móvil brinda servicio a los usuarios al interior del vehículo y adiciona, a las funcionalidades de un eNB tradicional, un subconjunto de funcionalidades de UE para conectarse a la DeNB. Cuando la conexión de la interfaz Un cambia de DeNB, el relay móvil mantiene la conectividad ininterrumpida, tanto en el plano de usuario, como en el de control de los UE servidos, hacia los elementos de núcleo de la red (3GPP TSGRAN, 2014a).

De las seis arquitecturas definidas en el TR 36.836, dos se continuarán trabajando para prestar servicios en redes $5 \mathrm{G}(5 \mathrm{G}$ Forum, 2016).

Propuestas como las descritas por Haider, Dianati, y Tafazolli (2011), y Sui, Ren, y Sun (2013) muestran el impacto benéfico, a nivel de sistema, de la introducción de femtoceldas móviles. El concepto de femtocelda móvil [MFemtocelda, Mobile Femtocell] se define con base en los conceptos de relay móvil y femtocelda, y corresponde a una celda pequeña que tiene movilidad y dinámicamente puede cambiar la conexión con el núcleo de la red. Todos los usuarios servidos por la MFemtocelda y la propia MFemtocelda son vistos como una unidad por el eNodB. Una MFemtocelda puede ser desplegada fácilmente en vehículos de transporte público y, en términos prácticos, puede ser considerada una forma de despliegue de relays móviles (Haider et al., 2011).

Rathod (2013) destaca las ventajas, a nivel de tasa de transferencia de datos, del uso de celdas indoor en redes LTE; Ulvan, Bestak, y Ulvan (2010), por su parte, muestran mecanismos para la optimización de traspaso; y Karimi, Liu, y Wang (2012) presentan una propuesta de implementación de femtoceldas movibles en trenes de alta velocidad. Lo anterior demuestra que, con la implementación de este tipo de soluciones en medios de transporte masivo, se obtienen importantes ventajas.

Por otro lado, el proceso de traspaso en redes LTE tiene una alta importancia para garantizar a los usuarios el mantenimiento de las sesiones de datos establecidas con la red. En este sentido, Ahmad, Sundararajan, Othman, y Ismail (2017) proponen variaciones al algoritmo tradicional, con el propósito de obtener mejores resultados en la tasa de traspasos completos exitosos, manipulando distintos tipos de variables, tales como: patrones de movilidad, posición, margen de traspaso [HOM, HandOver Margin] y tiempo de disparo [TTT, Time to Trigger]. Sin embargo, la mayoría de trabajos están orientados a una arquitectura tradicional de red LTE.

Dado el gran número de usuarios de medios de transporte masivo, un proceso de traspaso que tenga en cuenta las características y condiciones de los relays móviles o las femtoceldas móviles puede: mejorar notablemente la tasa de traspasos exitosos, producir un menor número de interrupciones de sesión y ofrecer una mejor experiencia de servicio para todos los UE servidos al interior de dichos medios de transporte.

El presente trabajo estudia el proceso de traspaso en redes LTE, recopilando inicialmente trabajos sobre el traspaso en redes tradicionales y luego enfocándose en propuestas de algoritmos de traspaso orientadas a medios de transporte masivo. tectures for mobile relays were defined. This, in order to establish the foundations to provide service to the people using high speed trains via the implementation of backhaul mobile wireless networks. The mobile relays are base stations implemented in high speed trains. They are wirelessly connected to a DeNB through a $U n$ radio interface.

The mobile relay provides service to the users inside the vehicle and adds to the functionalities of a traditional eNB a subset of UE functionalities to connect to the DeNB. When the connection of the $U n$ interface changes of DeNB, the mobile relay maintains the connectivity uninterrupted in both the end user plane and in the control plane of the served UE towards the elements in the core of the network (3GPP TSGRAN, 2014a).

From the six architectures defined in the TR 36.836, two were selected to provide services in the upcoming $5 \mathrm{G}$ (5G Forum, 2016).

Other proposals, such as the ones described by Haider, Dianati, and Tafazolli (2011) and Sui, Ren, and Sun (2013) show the positive impact - at the system level - of the mobile femtocells introduction. The concept of mobile femtocell is defined based on the mobile relay and femtocell concepts. It consists of a small cell with mobility features, hence, it can dynamically change the connection with the network core. All the users served by the femtocell are seen as a single unit by the eNodeB and it can be easily deployed in public transportation vehicles. In practical terms, it can be considered as a way to deploy mobile relays (Haider et al., 2011).

Rathod (2013) highlights the advantages - in the data transfer level - of the indoor cells usage in LTE networks; Ulvan, Bestak, and Ulvan (2010) show mechanisms to optimize the handover process; and Karimi, Liu , and Wang (2012) present a mobile femtocell implementation proposal in high speed trains. This demonstrates that, with the advantages in the implementation of this type of solutions in massive means of transport, important advantages are reached.

On the other hand, the handover in LTE networks has a large importance to guarantee to the users the maintenance of the data sessions established with the network. Ahmad, Sundararajan, Othman, and Ismail (2017) propose variations to the traditional handover algorightm, seeking to obtain better results in the successfully performed handovers rate by manipulating several variables such as: mobility patterns, position, Handover Margin [HOM], and Time to Trigger [TTT]. Nevertheless, most of the research works are oriented towards a traditional LTE architecture.

Due to the large number of users in massive means of transport, a handover process considering the features and conditions of the mobile relays or femtocells can improve notably the rate of successful handovers, produce a lower 
number of session interruptions, and offer a better service experience for all the UEs served inside them.

The current research article studies the handover process in LTE networks by initially assessing other works related with the handover in traditional networks. After that, we focus in handover algorithm proposals oriented to massive means of transport.

\section{Method}

Initially, we proceeded to review the 3GPP Technical reports related with the handover process in LTE supporting mobile relays. This, to understand the standard handover process proposed in those reports. In general, we reviewed research works between 2009 and 2017, together with specialized articles about fixed and mobile relays and femtocells. After, we reviewed documents related with the handover process, to finally focus our work on the algorithms related with the handover process in LTE networks in massive means of transport.

\section{Handover Process in LTE Networks}

\section{A. Handover Process in Fixed Cells}

Within LTE, the UEs can be in two modes: connected or free. In the first one, they introduce the handover process; in the second, they execute the initial cell selection and re-selection processes. The handover process allows to transfer a data session from one cell to another without interruptions. It can be intra-frequency, inter-frequency over the same system, or intersystem towards UMTS or GSM networks.

The handover is triggered via events (3GPP-TSGRAN, 2015) where either the serving or the neighbor cell exceed certain configured Reference Signal Received Power [RSRP] threshold. In LTE, the following intra Radio Access Technology [RAT] events exist:

- Al, the level of the serving cell is higher than the configured threshold;

- A2, the level of the serving cell is lower than the configured threshold;

- A3, the level of a neighbor cell is somewhat higher than the level of the serving cell;

- A4, the level of the neighbor cell is higher than the configured threshold; and

- A5, the level of the serving cell is lower than a first threshold and the level of the neighbor cell is higher than the second threshold.

In compliance with the previous events, two handover types are available: based on the A3 event, as shown in FIGURE 1; and based on the event A5, shown in Figure 2.

The HOM allows to configure the difference in the signal level of the target cell over the serving one, i.e., the RSRP

\section{Método}

Inicialmente, se procedió a revisar los reportes técnicos del 3GPP relacionados con el proceso de traspaso en LTE y con el soporte de relays móviles, para comprender el proceso de traspaso estándar que se plantea en dichas alternativas. En general, se revisaron trabajos comprendidos entre 2009 y 2017, y artículos especializados en el tema, incluyendo trabajos relacionados con relays y femtoceldas fijas y móviles en LTE. Posteriormente, se revisaron trabajos relacionados con el proceso de traspaso, para finalmente enfocar el trabajo hacia los algoritmos orientados a traspaso de LTE en medios de transporte masivo.

\section{Proceso de traspaso en redes LTE}

\section{A. Proceso de traspaso en celdas fijas}

En LTE, el UE puede permanecer en modo conectado o en modo libre: en el primero, presenta el proceso de traspaso; en el segundo, ejecuta los procesos de selección inicial de celda y de re-selección. El proceso de traspaso permite trasferir una sesión de datos de una celda a otra sin interrupciones de la sesión. El traspaso puede ser: intra-frecuencia, inter-frecuencia sobre el mismo sistema o inter-sistema, hacia redes UMTS o GSM.

El traspaso se dispara mediante eventos (3GPP-TSGRAN, 2015) en donde la celda servidora o la celda vecina superan cierto umbral configurado de Potencia Recibida de la Señal de Referencia [RSRP, Reference Signal Received Power]. En LTE, se tienen los siguientes eventos intra-RAT [Radio Access Technology]:

- evento Al, el nivel de la servidora es mayor que un umbral configurado;

- evento A2, el nivel de la servidora es menor que un umbral configurado;

- evento A3,el nivel de una celda vecina llega a ser cierto margen mayor que la celda servidora;

- evento A4,el nivel de la celda vecina llega a ser mayor que un umbral configurado; y

- evento A5, el nivel de la celda servidora llega a ser menor que un umbral 1 y el nivel de la celda vecina llega a ser mayor que un umbral 2.

De acuerdo con los eventos, se tienen dos tipos de traspaso: con base en el evento A3, como se muestra en la Figura 1; y con base en el evento A5, como se muestra en la Figura 2.

El Margen de Traspaso [HOM, HandOver Margin] permite configurar la diferencia del nivel de señal de la celda candidata sobre la celda servidora, es decir, el nivel RSRP de la celda destino deberá ser superior en dicho margen a la servidora actual. El Tiempo de Disparo [TTT, Time to Trigger] permite retrasar el inicio del proceso de traspaso, para evitar traspasos innecesarios que producen un efecto ping-pong, por lo tanto, la celda destino deberá mantener el nivel superior de señal, al menos durante dicho TTT, para evitar disparos de traspaso innecesarios durante variaciones de posibles celdas destino.

$B$. Proceso de traspaso en relays móviles

El 3GPP especifica seis alternativas en cuanto a arquitectura para relays móviles, denominadas: Alt.1, Alt.2, eAlt.2-1, eAlt.2- 
RSRP
(dBm)

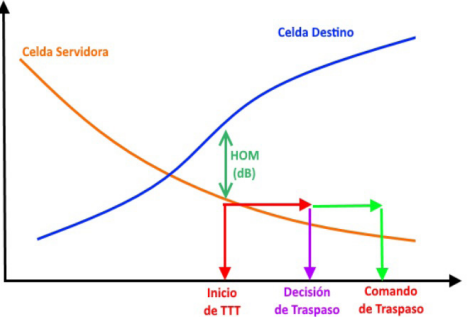

Figure 1. A3 event for the handover process / Evento A3 para proceso de traspaso

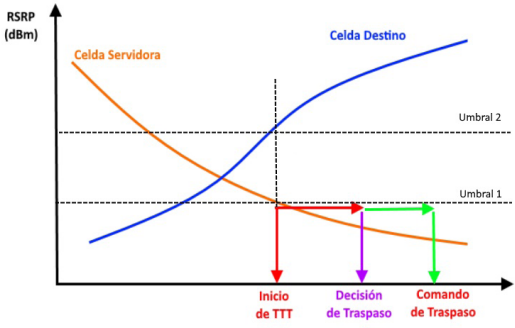

Figure 2. A5 event for the handover process / Evento A5 para proceso de traspaso level of the target cell shall be superior in that margin over the current cell. The TTT allows to delay the handover start time to avoid unnecessary handovers that produce a ping-pong effect. Consequently, the destination cell must maintain the highest signal level at least during the TTT to avoid the triggering of unnecessary handovers during variations of possible target cells.

\section{B. Handover Processing Mobile Relays}

The 3GPP specifies six alternatives regarding the architecture for mobile relays, called: Alt.1, Alt.2, eAlt.2-1, eAlt.2-2, eAlt.23, and Alt.4 (3GPP TSGRAN, 2014a). Within the Alt.1 architecture - also called Relay Full L3-, the SGW/PGW entities serving the relays network are separated from the donor cell. One of the advantages of this architecture is the fact of providing a simpler handover and during the switch of the return network link through the source and sink donor stations (means of transport in movement), a stable anchor point is maintained at IP level. This ensures the group mobility support of the users served by the relay (Krendzel, 2013).

In Figure 3, we show the handover process for the Alt.1 architecture of mobile relays, which is identical to the eNB handover process for a defined UE by the 3GPP (3GPP TSGRAN, 2017).

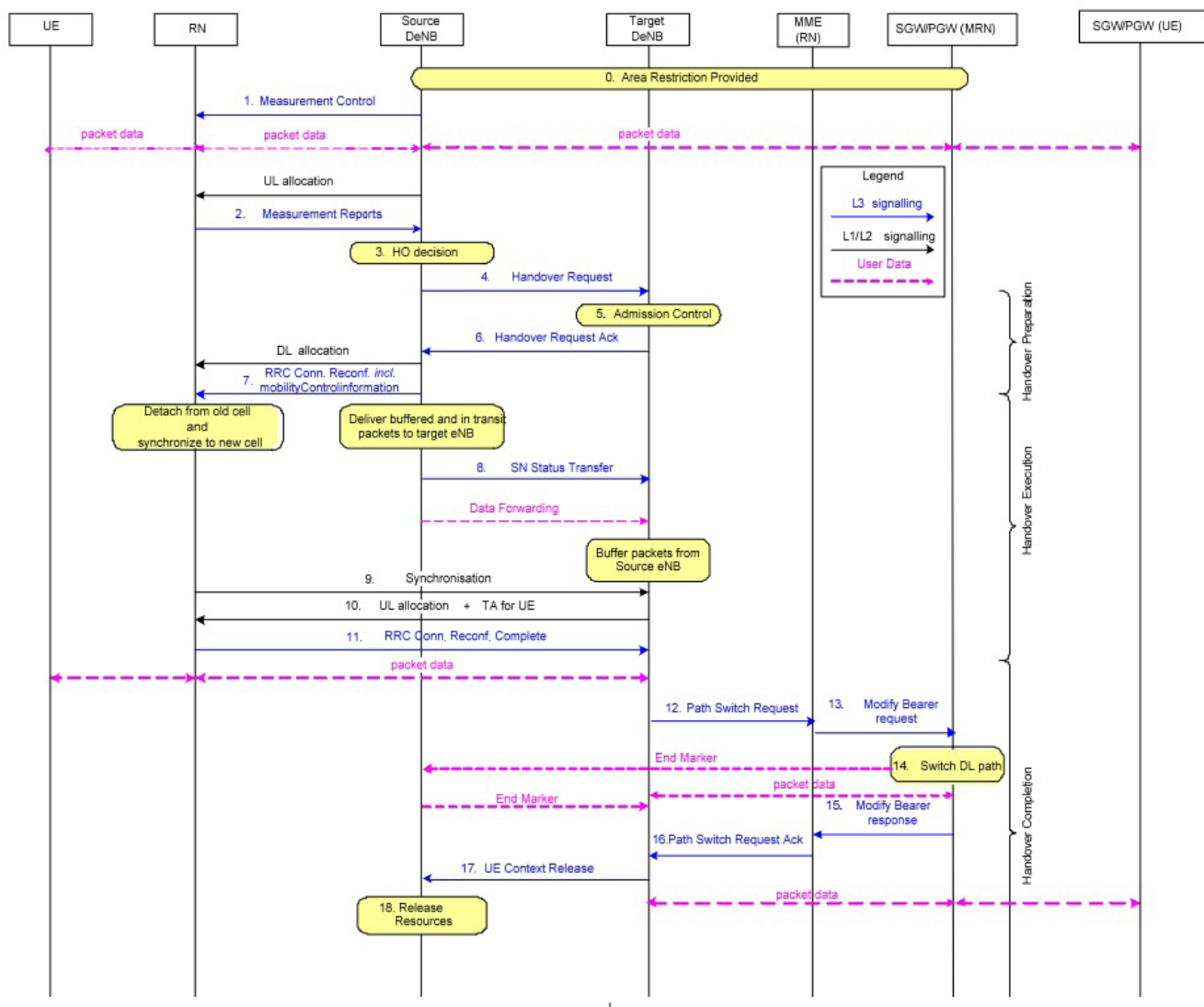

Figure 3. Handover process for the Alt.1 of 3GPP TR 36.836 mobile relays / Proceso de traspaso para la Alt1 de relays móviles 3GPP TR 36.836 (3GPP-TSGRAN, 2010) 


\section{Handover Algorithms in LTE Networks}

Dimou et al., (2009) assessed the hard handover behavior defined by the 3GPP for LTE networks. They performed several simulations in different environments, varying the cell size, traffic load, and UE speed. Their results show that, for cells with a radius up to $1 \mathrm{~km}$, UE speeds up to 120 $\mathrm{km} / \mathrm{h}$, and a system with large traffic loads, the handover failure rate was between $0 \%$ and $2.2 \%$. For systems with medium and low traffic load and speeds up to $250 \mathrm{~km} / \mathrm{h}$, the failure rate was under $1.3 \%$.

Ahmad et al., (2017) presented a review of the LTE/ LTE-A control plane, the several phases, requirements, parameters, and features of the handover process. Further, they present a study of a significative amount of algorithm proposals for the handover process in LTE-A networks. Their work classifies the revised proposals in four kinds depending on its base in: algorithms based on mobility patter$\mathrm{ns}$, based on direction and location, based on self-optimization, and based on multiple hops usage.

The algorithms based on mobility patterns (Watanabe, Matsunaga, Kobayashi, Sugahara, \& Hamabe, 2011; Wang, Huang, \& Tung, 2014; Tao, Yuan, Hong, \& Zhang, 2016; Ge, Wen, \& Zheng, 2009) seek the construction of a mobility history for the user; this, in order to predict the UE movements inside the network. This way, they also search to predict the candidate cells for the handover. Tao et al., (2016) propose the reconnaissance of an intelligent mobility pattern - called Smart-HO_, executed in three stages: pattern modelling, pattern reconnaissance, and implementation of the intelligent handover. Watanabe et al., (2011) propose a scheme for handling the list of neighbor cells, giving higher priority to the new detected cells over the existing ones. Wang et al., (2014) and Ge et al., (2009) propose handover schemes based on the construction of mobility records for the users

The algorithms based on direction and location group that work with the UE location via GPS are characterized by the fact of knowing the network topology and the UE movements. They seek to improve the handover process (Chen, Kim, \& Yoo, 2014; Chang, Wang, Hu, \& Kao, 2013; Lee, Cho, \& Kim, 2005). Likewise, Chen et al., (2014); Chang et al., (2013) and Wang, Kao, Hsiao, and Chang (2014) propose a handover technique based on the tracking of the latest UE positions using GPS. By having the previous positions - P1 and P2 - and the current position (P3), the technique tries to determine the future position and the corresponding candidate cell for the handover, achieving a reduction in the number of unnecessary handovers.

The algorithms based on self-optimization are featured by performing a self-adjustment process in the network
2, eAlt.2-3 y Alt.4 (3GPP TSGRAN, 2014a). En la arquitectura de Alt.1, denominada Relay Full L3, las entidades de SGW/ PGW que sirven a la red de relays están separadas de la celda donante. Entre las ventajas de la Alt.1 se destaca un proceso de traspaso más simple y que durante el cambio del enlace de red de retorno a través de las estaciones donantes origen y destino (medio de transporte en movimiento), se mantiene un punto de anclaje estable a nivel de IP, por lo cual soporta la movilidad a nivel grupal de los usuarios servidos por el relay (Krendzel, 2013).

En la Figura 3 se muestra el proceso de traspaso para la Alt1 de relays móviles, que es idéntico al proceso de traspaso Inter eNB para un UE definido por el 3GPP (3GPP TSGRAN, 2017).

\section{Algoritmos de traspaso en redes LTE}

Dimou et al., (2009) evalúan el comportamiento del traspaso duro definido por el 3GPP para redes LTE explicado. Realizaron varias simulaciones con diferentes entornos, variando el tamaño de las celdas, la carga de tráfico y la velocidad de los UE, las cuales mostraron que para celdas de hasta $1 \mathrm{Km}$ de radio, velocidades de hasta $120 \mathrm{Km} / \mathrm{h}$ de los UE y un sistema con alta carga de tráfico, la tasa de fallas variaba de 0 a 2,2\%. Para sistemas con media y baja carga de tráfico y velocidades de hasta $250 \mathrm{~km} / \mathrm{h}$, la tasa de falla era inferior a $1,3 \%$.

Ahmad et al., (2017) presentan una revisión del plano de control de LTE/LTE-A, las distintas fases, los requerimientos, los parámetros y las características del proceso de traspaso, así como un estudio de una cantidad importante de propuestas de algoritmos para procesos de traspaso en redes LTE-A. Su trabajo clasifica las propuestas revisadas en cuatro clases, dependiendo de su base, así, algoritmos basados: en patrones de movilidad, en dirección y localización, en auto-optimización y en utilización de múltiples saltos.

Los algoritmos basados en patrones de movilidad (Watanabe, Matsunaga, Kobayashi, Sugahara, \& Hamabe, 2011; Wang, Huang, \& Tung, 2014; Tao, Yuan, Hong, \& Zhang, 2016; Ge, Wen, \& Zheng, 2009) buscan la construcción de un historial de movilidad del usuario, con el fin de predecir los movimientos del UE dentro de la red, y así predecir también las celdas candidatas para traspaso. Tao et al., (2016) proponen el reconocimiento de un patrón de movilidad inteligente, denominando Smart-HO, el cual se ejecuta en tres fases: modelamiento del patrón, reconocimiento del patrón e implementación del traspaso inteligente. Watanabe et al., (201 1) proponen un esquema para el manejo de la lista de celdas vecinas, dando mayor prioridad a las nuevas celdas detectadas, sobre las existentes. Wang et al., (2014) y Ge et al., (2009) proponen esquemas de traspaso basados en la construcción de un historial de movilidad del usuario.

Los algoritmos basados en dirección y localización agrupan algoritmos que trabajan con la ubicación de los UE mediante GPS; conociendo la topología de la red y el movimiento de los UE, buscan mejorar el proceso de traspaso (Chen, Kim, \& Yoo, 2014; Chang, Wang, Hu, \& Kao, 2013; Lee, Cho, \& Kim, 2005). Por su parte, Chen et al., (2014); Chang et al., (2013) y Wang, Kao, Hsiao, \& Chang (2014) proponen una técnica de 
traspaso basado en el rastreo de las últimas posiciones del UE utilizando GPS. Teniendo las posiciones previas P1, P2 y la posición actual (P3), se trata de determinar la posición futura y la correspondiente celda candidata para el traspaso, con lo que se logra reducir el número de traspasos innecesarios.

Los algoritmos basados en auto optimización agrupan algoritmos en los cuales se realiza un proceso de auto ajuste de los parámetros de red (Lee, Gil, \& Kim, 2010; Yang, Deng, Jiang, \& Deng, 2015; Balan, Jansen, \& Sas, 2011: Jansen, Balan, \& Turk, 2010). Por su parte, Isa, Baba, y Yusof (2015) describen, como métodos para la optimización del traspaso: la modificación del umbral de RSS y la histéresis, la modificación del TTT y la modificación del filtrado de eventos A3 en el procedimiento de traspaso. Li y Wang (2013); Sinclair, Harle, Glover, Irvine, y Atkinson (2013); y Muñoz, Barco, y Fortes (2014) proponen mecanismos para el manejo del traspaso en redes LTE mediante funcionalidades implementadas en herramientas SON [Self-Organizing Networks]. Lee et al., (2010) proponen un esquema adaptativo de histéresis usando un algoritmo de función de costos, con el propósito de reducir las fallas de radio enlace en el proceso de traspaso. La función de costos depende de la suma de los pesos de tres parámetros: el balance de carga entre la celda servidora y la celda destino, la velocidad del UE y la Calidad del Servicio [QoS, Quality of Service] (si corresponde o no a servicios de tiempo real).

Zheng, Wang, Zhang, Lu, y Wen (2009) proponen una optimización del parámetro de traspaso teniendo en cuenta el número de cruces de límite de celda, los cuales se pueden obtener contando los cambios de identificador de celda. Los parámetros de TTT, histéresis e intervalo de medida son ajustados comparando el número de traspasos por efecto ping-pong, con el número de traspasos ejecutados en un periodo de medida.

Su, Wen, Zhang, y Zheng (2010) proponen un mecanismo de optimización de los parámetros de traspaso para SON, teniendo en cuenta el número de cruces del límite de celda y el número de traspasos ejecutados por el UE, la medida de la intensidad de señal es utilizada, exclusivamente, para seleccionar la celda destino en la decisión de traspaso.

Los algoritmos basados en múltiples saltos (Jengyueng, Chunchuan, \& Yiting, 2015; Lin, Sandrasegaran, \& Zhu, 2012; Lin, Sandrasegaran, \& Reeves, 2012; Tu, Lin, \& Chang, 2012; Chen, Mai, \& Yang, 2012) se basan en nuevas características de la red de acceso soportadas por LTE-A. El procedimiento de traspaso es afectado por: la interferencia intercelda, el ancho de banda, la cobertura y la capacidad de las celdas, por lo tanto, el proceso de traspaso podría adaptarse a las nuevas características. Dentro de este grupo se manejan los algoritmos relacionados con relays y técnicas de multipuntos coordinados [CoMP, Coordinated Multipoint]. Jengyueng et al., (2015) y Chen et al., (2012) proponen un mecanismo de reenvío inteligente para mejorar el desempeño del traspaso en redes LTE-A con nodos de relays. Lin, Sandrasegaran, y Zhu (2012) y Lin, Sandrasegaran, y Reeves (2012) proponen algoritmos de traspaso con soporte para CoMP JP. Lin, Sandrasegaran, y Zhu (2012) proponen un algoritmo de parameters (Lee, Gil, \& Kim, 2010; Yang, Deng, Jiang, \& Deng, 2015; Balan, Jansen, \& Sas, 2011; Jansen, Balan, \& Turk, 2010). Equally, Isa, Baba, and Yusof (2015) describe methods for the handover optimization such as the modification in the RSS threshold and hysteresis, modification of the TTT, and modification of the filtering action for A3 events in the handover. Li and Wang (2013); Sinclair, Harle, Glover, Irvine, and Atkinson (2013); and Muñoz, Barco, and Fortes (2014) propose mechanisms for the handover treatment in LTE networks via implemented functionalities in Self-Organizing Networks [SON] tools. Lee et al., (2010) propose an adaptive hysteresis scheme using a costs function algorithm seeking to reduce the failures in the radio link during the handover process. The costs function depends on the sum of the weights of three parameters: the load balance between the served and target cell, the UE speed, and the Quality of Service [QoS] (if real-time services are relevant or not).

Zheng, Wang, Zhang, Lu, and Wen (2009) propose an optimization of the handover parameters by considering the number of limit crosses per cell, which can be obtained by counting the changes in the cell identificator. The TTT, hysteresis, and measurement interval parameters are adjusted by comparing the number of handovers by ping-pong effect with the number of handovers in a measurement period.

Su, Wen, Zhang and Zheng (2010) propose an optimization mechanism of the handover parameters for SON by considering the number of limit crosses per cell and the number of handovers executed by the UE. The measurement of the signal intensity is exclusively used to select the destination cell in the handover decision.

The algorithms based on multiple hops (Jengyueng, Chunchuan, \& Yiting, 2015; Lin, Sandrasegaran, \& Zhu, 2012; Lin, Sandrasegaran, \& Reeves, 2012; Tu, Lin, \& Chang, 2012; Chen, Mai, \& Yang, 2012) use new features of the access networks supported by LTE-A. The handover procedure is affected by the intercell interference, bandwidth, coverage, and cellscapacity. Therefore, the handover process might be adapted to the new features. Within this group, the algorithms related with relays and Coordinated Multipoint [CoMP] techniques are employed. Jengyueng et al., (2015) and Chen et al., (2012) propose an intelligent forwarding mechanism to improve the handover performance in LTE-A networks with relay nodes. Lin, Sandrasegaran, and Zhu (2012), and Lin, Sandrasegaran, and Reeves (2012) propose handover algorithms with CoMP JP support. Lin, Sandrasegaran, and Zhu (2012) propose a handover algorithm with CoMP integrated capacity, whose purpose is to ensure the efficient use of the radio resources regarding capacity and channel quality. This is done by em- 
ploying historical records of the RB usage in the cell and, consequently, defining a new handover parameter called capacity indicator. This parameter is employed by the algorithm to determine an appropriate destination cell. Tu et al., (2012) propose a handover scheme based on prediction to allow the eNB to have a potential handover trigger within the report period of the UE, where the channel quality from both the donor and the relay are predicted through a Markov decision process.

\section{Handover Algonithms in LTE Networks Focused on Means of Transport}

In the following sections, we describe other research works relative to handover algorithms and specially focused on means of transport. We have organized the works in four groups: algorithms proposing modifications in the network architecture, algorithms associated to the UE mobility, setup algorithms based on the signal level, and algorithms focused on mobile relays.

\section{A. Algorithms with Architecture Modifications}

Here, we present the works involving modifications to the standard network architecture or proposing a different handover type than the hard handover used in LTE.

Wang, Ren, and Tu (2011) describe a soft handover for TD-LTE in a high-speed trains scenario by seeking the reduction in the number of Radio Link Failure [RLF] and the ping-pong effect. Furthermore, the proposal pursues the minimization in the interruption time caused by the high speeds to provide a satisfactory user experience. The algorithm grants a list for each UE inside the scenario and each of these handover lists has the control information in the downlink of two neighbor eNBs. Nevertheless, only a single transmission in the downlink is considered from the eNB with better RSRP. The algorithm is based on the eNodeB adding/removal steps to the list, depending on the RSRP thresholds.

On the other hand, the semi-soft handover algorithm for multi-bearer systems based on the Site Selection Diversity Transmission [SSDT] is a macro-diversity method employed in soft handovers over WCDMA networks. Its objective is to reduce the inter-cell interference caused by multiple transmissions while the transmission is performed in the downlink from the best serving cell. In the semi-soft handover, the bandwidth is divided in two different bands: control and data. The control band, with a frequency reuse factor of 7, is divided in 7 sub-bands, each one of them handled by a cell. A UE can - simultaneously - receive information from all the neighbor cells through the control channels and select the cell with higher RSRP to transmit packets via SSDT. According to the simulations performed in the study, a better performance in the number of success- traspaso de capacidad integrada CoMP, que busca asegurar el uso eficiente de los recursos radio en cuanto a capacidad y calidad del canal, empleando un histórico de la utilización de RB en la celda, y con ello definiendo un nuevo parámetro de traspaso denominado indicador de capacidad, usado en el algoritmo para determinar una apropiada celda destino. Tu et al., (2012) proponen un esquema de traspaso basado en predicción, para permitir a los eNB un potencial disparo de traspaso dentro del periodo de reporte de los UE, en donde la calidad del canal, tanto de la donante, como del relay, se predicen mediante un proceso de decisión de Markov.

V. Algoritmos de traspaso en redes LTE enfocados en medios de transporte

A continuación se describen otros trabajos de algoritmos de traspaso, especialmente enfocados en medios de transporte. Los trabajos se han organizado en cuatro grupos: algoritmos que proponen modificaciones de arquitectura, algoritmos asociados a movilidad de los UE, algoritmos de ajustes basados en niveles de señal y algoritmos enfocados en relays móviles.

\section{A. Algoritmos con modificación de arquitectura}

En esta sección se describen trabajos que involucran modificaciones a la arquitectura de la red estándar o que proponen un tipo de traspaso distinto al traspaso duro utilizado en redes LTE.

Wang, Ren, y Tu (2011) describen un traspaso suave para TD-LTE para un escenario de trenes de alta velocidad, buscando reducir el número de Fallas de Radio Enlace [RLF, $R a-$ dio Link Failure] y el efecto de ping-pong, y minimizar el tiempo de interrupción causado por la alta velocidad, para así tratar de proveer una experiencia de usuario satisfactoria. El algoritmo provee una lista para cada UE dentro del escenario. Cada lista de traspaso contiene la información de control en el enlace descendente de dos eNodeBs vecinos. El UE conecta con los dos eNodeBs y se reservan recursos radio para el UE en ambos eNodeBs. Sin embargo, sólo se tiene una transmisión en enlace descendente en cada trama, desde el eNodeB con mejor RSRP. El algoritmo se basa en los pasos de adición o remoción de eNodeBs a la lista, dependiendo de umbrales de RSRP.

Por otro lado, el algoritmo de Traspaso Semi-suave para Sistemas Multiportadora Basados en la Diversidad por Selección de Estación Base [SSDT, Site Selection Diversity Transmission] es un método de macro diversidad usado en traspaso suave en redes WCDMA. Su objetivo es reducir la interferencia intercelda causada por múltiples transmisiones, mientras se transmite en enlace descendente desde la mejor celda servidora. En el traspaso semi-suave se divide el ancho de banda en dos bandas distintas: una de control y otra de datos. La banda de control, con factor de reuso de frecuencia de siete, se divide en siete sub-bandas, cada una de ellas manejada por una celda. Un UE puede, simultáneamente, recibir información de todas las celdas vecinas, a través de los canales de control, y seleccionar la celda con mayor RSRP para transmitir paquetes vía SSDT. De acuerdo con las simulaciones realizadas en dicho estudio, se obtiene un mejor desempeño en el número de traspasos exitosos, sin embargo, al recibir señales de control desde todas las 
vecinas, se incrementa el sobreencabezamiento en la señalización (Lee, Son, \& Lee, 2009).

El esquema propuesto por Lee, Chuang, Chen, y Sun (2014) se basa en femtoceldas LTE que usan múltiples interfaces de salida, denominada Red de Múltiple Salida [MEN-NEMO, Multiple Egress Network - Network Mobility] para reducir la latencia y el sobreencabezamiento en el proceso de traspaso. Para la arquitectura de núcleo de red, se propone la utilización de femtoceldas mejoradas desplegadas en el tren para brindar servicio a los UE de los pasajeros. De acuerdo con las simulaciones realizadas, con el esquema propuesto se consigue disminuir la latencia y el sobreencabezamiento de la señalización del proceso de traspaso.

\section{B. Algoritmos basados en movilidad de los UE}

En esta sección se incluyen algoritmos que utilizan la velocidad y posición del UE para disparar el proceso de traspaso.

Luan, Wu, Shen, Ye, y He (2012) proponen dos tipos de algoritmos de traspaso LTE para trenes de alta velocidad, denominados algoritmos de traspaso rápido: uno basado en la velocidad del UE, otro en la optimización de la TTT. En el primero se propone ajustarla histéresis y el TTT del traspaso de manera dinámica, de acuerdo con la velocidad del tren, para asegurar un proceso de traspaso exitoso; con el algoritmo propuesto, cuando la velocidad se incrementa, tanto la histéresis, como el TTT, sufren pequeños decrementos. De acuerdo con las simulaciones, se logra mejorar la Tasa de Traspasos Satisfactorios [HSR, Handover Success Rate] para ciertos valores de relación señal a ruido [SINR, Signal to Interference plus Noise Ratio]. En el segundo, se tienen en cuenta las variaciones de RSRP y RSRQ de la celda servidora y la celda destino producidas por la velocidad del tren; por lo tanto, se propone ajustar los márgenes de histéresis y, para evitar el efecto de ping-pong, se define un número $\mathrm{N}$ de veces que las medidas de la celda destino excedan a la de origen. Con estas condiciones, el TTT variará dinámicamente para reflejar las condiciones del canal y evitará fallas de traspaso y efecto de ping-pong. Similar al caso anterior, de acuerdo con las simulaciones, se consigue mejorar el HSR para ciertos valores de SINR.

En el trabajo de Zhang, Wu, Zhang, y Luan (2014), se analiza un escenario de trenes de alta velocidad y la dirección del movimiento del tren, junto con datos de GPS que se supone son fáciles de obtener. Las celdas vecinas a lo largo de las vías también son conocidas, por lo cual se propone utilizar toda ésta información para implementar un esquema de traspaso rápido. El esquema propuesto brinda puntos de referencia apropiados para disparar un procedimiento de traspaso. El algoritmo propuesto permite reducir la latencia y tener áreas de solapamiento más pequeñas para el procedimiento de traspaso. La selección de un adecuado punto de referencia (ubicación geográfica) para la realización del traspaso es fundamental, por lo tanto, los puntos corresponden al resultado estadístico de repetidas medidas. Mediante la utilización del parámetro de histéresis y medidas de tasa de bloques errados [BLER, Block Error Rate], se trata de determinar los puntos geográficos en donde se debe realizar el disparo del traspaso hacia la celda destino. ful handovers is obtained; nevertheless, when control signals are received from all the neighbor cells, the number of headers in the signaling is increased (Lee, Son \& Lee, 2009).

The scheme proposed by Lee, Chuang, Chen, and Sun (2014) is based on LTE femtocells using multiple output interfaces - called Multiple Egress Network - Network Mobility [MEN-NEMO] - to reduce the latency and the number of headers in the handover process. For the network core architecture, the authors propose the usage of improved femtocells deployed in the train to provide service to the passengers' UEs. In accordance with the performed simulations, the proposed scheme was able to reduce the latency and the number of headers in the signaling for the handover processes.

\section{B. Algorithms Based on the UE Mobility}

Here, we present some algorithms that use the UE speed and position to trigger the handover process. Luan, Wu, Shen, Ye, and He (2012) propose two types of LTE handover algorithms for high speed trains, called fast handover algorithms: one based on the UE speed and the other based on the TTT optimization. The first one proposes to adjust the handover hysteresis and TTT dynamically and according to the train speed to ensure a successful handover. With this, when the speed is increased, both the hysteresis and the TTT suffer small decrements. According with the simulations, the Handover Success Rate [HSR] is improved for certain values of Signal to Interference plus Noise Ratio [SINR]. Within one second, the RSRP and RSRQ variations from the serving and destination cells produced by the train speed are considered. Therefore, the authors propose to adjunt the hysteresis margins and, to avoid the ping-pong effect, they define a number of times $\mathcal{N}$ that the target cell measurements exceed the source ones. With these conditions, the TTT will dynamically vary to reflect the channel conditions and it will avoid handover failures and the ping-pong effect. Similar to the previous case, given the simulation results, the HSR is improved for certain SINR values.

The work presented by Zhang, Wu, Zhang, and Luan (2014) analyzes a high-speed trains scenario, where the train direction is considered together with the GPS data, which are relatively easy to obtain. The neighbor cells through the railways are also known; hence, they propose to use this information to implement a fast handover scheme. Their proposal settles appropriate reference points to trigger a handover procedure and their algorithm allows to reduce the latency and having smaller overlapping areas for the handover. The selection of an adequate reference point (geographic location) to perform the handover is fundamental; consequently, the points correspond to the sta- 
tistical result of repetitive measurements. With the use of the hysteresis parameter and the measurement of the Block Error Rate [BLER], the authors tried to determine the geographical points where the handover must be triggered to send the session towards the destination cell. As per their simulation results, the ping-pong effect is reduced and they obtained a favorable radiolink failure rate.

\section{Algorithms Based on Adjustments in the Signal Level}

We present some algorithms using an adjustment in the handover parameters based on the received signal levels. The work of Anas, Calabrese, Mogensen, Rosa, and Pedersen (2007) uses a TTT window based in the Received Signal Strenght [RSS]. The instantaneous RSRP value is stored in a record, whose values are later processed to determine if the handover must be triggered. The algorithm is implemented in two stages: storage and comparison in the signal level. As per their simulation results, they suggest HOM values to obtain a good relation between the number of executed handovers and the SINR.

The algorithm proposed by Zheng and Wigard (2008) considers the handover decision in the usage of historical records relative to differences in the signal level. The algorithm is executed in three stages: the calculation of the RSRP differences, the processing of the filtered RSRP values, and the handover decision. The simulation results show a reduction in the number of executed handovers by the UE; nevertheless, this algorithm does not consider the TTT, since the ping-pong effect is present.

The Hard Handover Algorithm with Average Received Signal Reference Power Constraint [LHHAARG] is a proposal seeking to minimize the number of handovers and delays, maximizing the data transfer in the network. LHHAARC is based on the hard handover algorithm with an additional condition over the average RSRP to improve the efficiency when the handover is executed (Link, Sandrasegaran, Ramli, \& Basukala, 2011).

The concept of the previous algorithm is mainly to limit the handover possibilities to minimize the unnecessary executions of it, ensuring the channel quality in the target cell by having a higher RSRP than the serving cell. This is executed by having certain threshold from the first to the last measurement period. Their results indicate that the number of handovers is reduced compared with the TTT window algorithms based on RSS and integrator. Furthermore, lower delay values were obtained, having a higher data transfer rate.

\section{Algorithms Designed for Mobile Relays}

In this section, we describe research works showing algorithms operating with mobile femtocells or mobile relays. Sui,Vihriälä, Papadogiannis, Sternad, Yang, and Svensson
De acuerdo con las simulaciones, se logra disminuir el efecto ping-pong y obtener una tasa de fallas de radio enlace favorable.

C. Algoritmos basados en ajustes por niveles de señal

En esta sección, se proponen algoritmos que utilizan un ajuste de los parámetros de traspaso basados en los niveles de señal recibida.

El trabajo de Anas, Calabrese, Mogensen, Rosa, y Pedersen (2007) utiliza una ventana de TTT basada en Intensidad de Señal Recibida [RSS, Received Signal Strength]. El valor de RSRP instantáneo se almacena en un historial, cuyos valores se procesan posteriormente para determinar si se procede a realizar el traspaso. El algoritmo se implementa en dos fases: almacenamiento de nivel de señal y comparación de nivel de señal. De acuerdo con los resultados obtenidos en simulaciones, se sugieren valores de HOM para obtener una buena relación entre el número de traspasos realizados y la SINR.

El algoritmo de Zheng \& Wigard (2008) basa la decisión de traspaso en la utilización de un histórico de diferencias de nivel de señal. El algoritmo se realiza en tres fases: el cálculo de diferencias de RSRP, el procesamiento de la diferencia de RSRP filtrada y la decisión de traspaso. Los resultados de las simulaciones muestran una disminución en el número de traspasos realizados por los UE, sin embargo, en este algoritmo no se considera el TTT, por lo que es posible que se presente el efecto de ping-pong.

El algoritmo LHHAARG [LTE, Hard Handover Algorithm with Average Received Signal Reference Power Constraint] es una propuesta que busca minimizar el número de traspasos y retardos, maximizando con ello la transferencia de datos de la red. LHHAARC se basa en el algoritmo de traspasoduro con una condición adicional sobre el RSRP promedio, para hacer más eficiente el desempeño del traspaso (Link, Sandrasegaran, Ramli, \& Basukala, 2011).

El concepto del anterior algoritmo consiste en limitar las posibilidades de traspaso para minimizar los traspasos innecesarios, y asegurar así la calidad de canal de la celda destino, teniendo un RSRP más alto que el de la celda servidora - con cierto umbral-, desde el primer hasta el último periodo de medidas. De acuerdo con las simulaciones realizadas, se logra obtener un número menor de traspasos por UE que los algoritmos de ventana de TTT basados en RSS e integrador, se obtiene también un menor retardo y, por tanto, una mayor tasa de transferencia de datos.

\section{Algoritmos diseñados para relays móviles}

En esta sección se describen trabajos que muestran algoritmos cuyo funcionamiento está diseñado para operar con femtoceldas móviles o relays móviles.

Sui,Vihriälä, Papadogiannis, Sternad, Yang, y Svensson (2013) estudian el despliegue de los denominados Nodos de Relay en Movimiento [MRN, Moving Relay Node] en vehículos de transporte público, para brindar servicio a los pasajeros de dichos vehículos. Se analiza el comportamiento en comparación al desempeño con un relay fijo. Para el estudio se realizaron varias simulaciones utilizando un relay fijo a distintas dis- 
tancias de un vehículo cuya posición se asume conocida. Las simulaciones muestran que los usuarios dentro del vehículo se ven afectados por las denominadas Perdidas de Penetración Vehicular [VPL, Vehicular Penetration Loss]. El análisis realizado muestra que mejoran considerablemente las VPL -y con ello la tasa de transferencia de datos de los usuarios-, colocando el relay lo más cercano posible al vehículo, razonamiento que permite concluir que el relay debería moverse con el vehículo, lo que a su vez conduce a la definición de relay móvil.

Karimi et al., (2012) presentan una solución basada en redes LTE para soportar una alta tasa de transferencia de datos y servicios multimedia continuos en trenes de alta velocidad. La solución utiliza un arreglo de celdas organizadas a lo largo de las vías del tren, junto con femtoceldas que soportan las demandas de tráfico al interior de cada vagón, denominadas eNBs móviles o femtoceldas móviles. Adicionalmente, se utiliza un proceso de traspaso denominado predictivo, donde el arreglo de celdas permite conocer con anticipación las celdas destino. Las simulaciones realizadas muestran que se obtienen mejoras a nivel de tasa de transferencia, una baja latencia de traspaso y una tasa de éxito de traspaso mayor.

Chen (2015) investiga los beneficios de los relays móviles en un escenario donde estos se despliegan en buses públicos. Aunque no propone específicamente un algoritmo de traspaso, su trabajo permite observar los beneficios de los relays móviles. El estudio se centra en tres aspectos: mejoras en los procedimientos de movilidad para relays móviles, en donde se estudian diferentes procedimientos de señalización y se propone mantener la misma pila de protocolos de los relays fijos; impacto de la interferencia de la tasa de transferencia de un UE vehicular, en donde se compara la tasa de transferencia de un UE conectado a la estación macro con la de otro conectado mediante el relay móvil; e impacto del relay móvil en la capacidad de la celda, en donde se estudia la ganancia de capacidad obtenida por el despliegue de relay en un escenario con múltiples usuarios y múltiples relays.

Davaasambuu \& Sato (2014) proponen un esquema de histéresis adaptativa de traspaso basada en una función de costo que considera algunos factores relevantes del relay móvil, tales como: la carga de las celdas, la velocidad del relay y el tipo de servicio requerido por el UE. El esquema opera entre celdas donantes para traspaso mediante la interfaz X2. De acuerdo con las simulaciones realizadas, el esquema propuesto presenta una mayor probabilidad de traspaso exitoso que un esquema basado en SINR.

En su trabajo, Davaasambuu, Yu, y Sato (2015) proponen un esquema de auto optimización de histéresis de traspaso con nodos de relays móviles duales en entornos de alta velocidad. Proponen un mecanismo de ajuste de los parámetros de traspaso histéresis y offset individual de las celdas, con base en la velocidad del vehículo, y un indicador de desempeño de traspaso [HPI, Handover Performance Indicator]. El HPI sirve para monitorear el desempeño del proceso de traspaso y corresponde a la suma de las tasas de falla de traspaso, traspaso de ping-pong y traspasos fallidos por fallas de radio enlace. En las simulaciones
(2013) study the deployment of the so-called Moving Relay Nodes [MRN] in public transportation vehicles to provide service to the passengers within them. They analyzed the behavior relative to the performance of a fixed relay. For the study, several simulations were carried out using a fixed relay at different distances from a vehicle - where its position is assumed as known - . Their results show that the users inside the vehicles are affected by the so-called Vehicular Penetration Loss [VPL] and that their algorithm considerably improves the user data transfer by reducing those VPL. This was achieved by locating the relay as close as possible to the vehicle, where the reader can infer that the relay should move with the vehicle, entailing in the concept of mobile relay.

Karimi et al., (2012) present a solution based on LTE networks to support a high data transfer and multimedia services in high speed trains. The solution employs an array of organized cells throughout the railways, together with femtocells supporting the traffic demand inside the trains. These last are called mobile eNB or mobile femtocells. Additionally, they use a handover process called predictive, where the cells array allows to know in advance the target cells. Their simulation results show that improvements at the transfer level are achieved, together with a low handover latency and a higher success rate in the handover execution.

Chen (2015) researches the benefits of the mobile relays in a scenario where they are deployed in public buses. Although the author does not specifically propose a handover algorithm, his work allows to observe the benefits of the mobile relays. His research is focused on three aspects: improvements in the mobility procedures for mobile relays, where several signaling procedures are studied and the same protocol stack of the fixed relays is employed; interference impact in the transfer rate of a vehicular UE, where the transfer rate of a UE connected to the macro station is compared with the one of a UE connected with the mobile relay; and impact of the mobile relay in the cell capacity, where the capacity gain obtained by the relay deployment is assessed in a scenario with multiple users and relays.

Davaasambuu and Sato (2014) propose an adaptive hysteresis scheme based on a cost function, which considers some relevant factors of the mobile relay such as the cell load, relay speed, and the service type requested by the UE. The scheme operates between handover donor cells via the $\mathrm{X} 2$ interface. Their results indicate that the proposed scheme presents a higher probability of a successful handover than a scheme based on SINR.

Davaasambuu, Yu, and Sato (2015) present a self-optimization hysteresis scheme with mobile relay dual nodes in high speed environments. They propose an adjustment mechansim of the handover parameters such as individual 
cell histeresis and offset based on the vehicle speed. Further, they propose a Handover Performance Indicator [HPI] as a measurement for their scheme. This HPI helps to monitor the handover performance and it is equal to the sum of the failure handover rate, ping-pong handover, and failed handovers due to radio link failures. The simulation results show that, when comparing the proposed scheme with the traditional one, the authors' one can reduce the number of radio link failures and service interruptions during the handover process.

On the other hand, Zhao, Huang, Zhang, and Fang (2011) propose an algorithm for the handover decision based on the Relative Velocity Aided Handoff [RVAH] of the UE towards the access points (cell, fixed or mobile relay), server, and destination. If the UE presents speeds lower than a threshold V0 regarding the server and destination access points, the handover will be performed according to the HOM and TTT; that is, the standard way. If the speed regarding the server access point is higher than the threshold V0, the handover process is triggered as per the RVAH algorithm. The neighbor access points with relative speeds lower than V0can be selected as future destination points.

Davaasambuu, Semaganga, and Sato (2015) propose an adaptive hysteresis scheme (based on the train speed) for handover in wireless networks with mobile relays in a high-speed trains scenario. They include a logarithmic formula involving the maximum and current speed of the mobile relay; also, they involve hysteresis values called "by default" and "maximum" for the hysteresis adjustment in the handover process. The probability of interruptions in calls during the handover is reduced by introducing a modified call admission control to support the savings in radio resources. This helps to prioritize the handover of the calls of the mobile relay over other calls. The authors present three priorities: mobile relay handover calls, UE handover calls, and new calls. The results described in their paper show how the successful handovers rate is increased and the radio failures is reduced.

\section{Vl. Conclusions}

In this paper, we carried out a revision of the handover algorithms, mainly focused in the algorithms oriented to massive means of transport. Although there are several handover algorithms in LTE presenting alternatives to adjust variables such as the HOM and TTT, other parameters as speed, position, and direction arose as key factors that must be considered in the algorithms oriented to means of transport.

In general, improvements in the successful handover rate are achieved with the implementation of new algorithms. Furthermore, other benefits are the reduction in the network signaling traffic, releasing resources in the control plane; re- realizadas, al comparar el esquema propuesto con el esquema tradicional de traspaso, se evidenció que el esquema propuesto puede reducir el número de fallas de radio enlace y las interrupciones de servicio durante el proceso de traspaso.

Zhao, Huang, Zhang, y Fang (2011), por su parte, proponen un algoritmo para la decisión de traspaso con base en la velocidad relativa [RVAH, Relative Velocity Aided Handoff] del UE hacia los puntos de acceso - celda, relay fijo o relay móvil-, servidor y destino. Si el UE presenta velocidades inferiores a un umbral V0, con respecto de los puntos de acceso servidor y destino, el traspaso se realizará de acuerdo con el HOM y TTT, es decir, mediante el proceso estándar; si la velocidad respecto del punto de acceso servidores es superior al umbral V0, se inicia el proceso de traspaso de acuerdo con el algoritmo RVAH. Los puntos de acceso vecinos con velocidades relativas inferiores a V0 podrán ser seleccionados como puntos destino.

Davaasambuu, Semaganga, y Sato(2015) proponen un esquema de histéresis adaptativa (basada en la velocidad del tren) para traspaso en redes inalámbricas con relays móviles, en un escenario de trenes de alta velocidad. Incluyen una formula logarítmica que involucra la velocidad máxima y la velocidad actual del relay móvil e involucran valores de histéresis, denominados "por defecto" y "máximo", para el ajuste de la histéresis del proceso de traspaso. La probabilidad de cortes de llamadas durante el traspaso se reduce introduciendo un control de admisión de llamada modificado, para soportar la reserva de recursos radio, de tal manera que priorice el traspaso de las llamadas del relay móvil sobre otras llamadas. Manejan tres prioridades: llamadas de traspaso del relay móvil, llamadas de traspaso de UE y nuevas llamadas. Las simulaciones realizadas en el trabajo muestran cómo se incrementa la tasa de traspasos exitosos y cómo se reduce el número de fallas de radio.

\section{Conclusiones}

En este trabajo se realizó una revisión de los algoritmos de traspaso, enfocada principalmente en los algoritmos orientados a medios de transporte masivo. Si bien distintos algoritmos de traspaso en LTE muestran alternativas para ajustar variables como el HOM y el TTT, otras variables como la velocidad, la posición y la dirección, surgen como factores clave que deben ser tenidos en cuenta en los algoritmos orientados a medios de transporte.

En general, se consiguen mejoras en la tasa de traspasos exitosos con la implementación de nuevos algoritmos y se obtiene además: la reducción de la señalización en la red, liberando recursos del plano de control; la disminución de la latencia; y la disminución de cortes en las sesiones, lo que se refleja, finalmente, en comunicaciones más estables y en una mayor tasa de transferencia de datos para los usuarios.

Los procesos ejecutados por los algoritmos de traspaso deben poseer una lógica simplificada que permita una rápida ejecución, para evitar fallas al nivel del enlace de radio, lo que es crítico en entornos de alta velocidad.

La implementación de relays móviles, incluidos por el 3GPP 
a partir del release12, ofrecerá ventajas significativas para los usuarios, en cuanto a la tasa de transferencia de datos y a la latencia. Los algoritmos enfocados en este tipo de soluciones constituyen un importante campo de estudio para trabajos futuros.SeT duction in the latency; and reduction in the session interruptions. This is finally reflected in more stable communications and in a higher data transfer rate for the end users.

The executed processes by the handover algorithms must have a simplified logic that allows a quick execution to avoid failures in the radio link level; this is critical in high speed environments.

The implementation of mobile relays - included by the 3GPP from the release12-, will offer significant advantages for the end users regarding the data transfer rate and latency. The algorithms focused on this type of solutions are an important study field for upcoming research works.ST 


\section{References / Referencias}

3GPP. (2017). Evolved Universal Terrestrial Radio Access (E-UTRA) and Evolved Universal Terrestrial Radio Access Network (E-UTRAN); Overall description; Stage 2. Retrieved from: http://www.3gpp.org/DynaReport/36-series.htm

3GPP TSGRAN. (2010). 3GPP TR 36.806 Relay architectures for E-UTRA (LTE-Advanced). Retrieved from: http://www.3gpp. org

3GPP TSGRAN. (2014a). 3GPP TR 36.836 Study on Mobile Relay. Retrieved from: http://www.3gpp.org

3GPP TSGRAN. (2014b). 3GPP TR 36.842 Scenarios and Requirements for Small Cell Enhancements for E-UTRA and E-UTRAN. Retrieved from: http://www.3gpp.org/DynaReport/36-series.htm

3GPP TSGRAN. (2013). 3GPP TR 36.839 Mobility enhancements in heterogeneous networks. Retrieved from: http://www. 3gpp.org/DynaReport/36-series.htm

3GPP TSGRAN. (2015). 3GPP TS 36.331 Protocol specification. Retrieved from:http://www.3gpp.org/DynaReport/36-series. htm

5G Forum. (2016). 5G vision, requirements and enabling technologies. Retrieved from: http://kani.or.kr/5g/whitepaper/5G\%20 Vision,\%20Requirements, \%20and\%20Enabling\%20Technologies.pdf

Ahmad, R., Sundararajan, E., Othman, N., \& Ismail, M. (2017). Handover in LTE-advanced wireless networks: state of art and survey of decision algorithm. Telecommun Syst, 66, 533-558.

Anas, M., Calabrese, F., Mogensen, P., Rosa, C., \& Pedersen, K. (2007). Performance evaluation of received signal strength based hard handover for UTRAN LTE. In IEEE 65th Vehicular Technology Conference (VTC2007-Spring), 1046-1050. IEEE.

Balan, I., Jansen, T., \& Sas, B. (2011). Enhanced weighted performance based handover optimization in LTE. In 2011 Future Network \& Mobile Summit. Warsaw. Retrieved from: https://ieeexplore.ieee.org/abstract/document/6095252/

Chang, F.-M., Wang, H.-L., Hu, S.-Y., \& Kao, S.-J. (2013). An efficient handover mechanism by adopting direction prediction and adaptive time-to-trigger in LTE Networks. In LNCS 7975: International Conference on Computational Science and Its Applications, (pp 270-280). doi:10.1007/978-3-642-39640-3_20

Chen, J.-Y., Mai, Y.-T., \& Yang, C.-C. (2012). Handover enhancement in LTE-advanced relay networks. In 2012 International Symposium on Computer, Consumer and Control. Taichung. doi:10.1109/IS3C.2012.64

Chen, X., Kim, M., \& Yoo, S. (2014). Efficient and prompt handover in LTE-based systems by predicting the target eNodeBs. In International Conference on Cyber-Enabled Distributed Computing and Knowledge Discovery. Shanghai. doi:10.1109/ CyberC.2014.77

Chen, Y. (2015). Performance analysis of mobile relays for LTE [thesis]. Universite de Rennes: France. Retrieved from: https:// hal.archives-ouvertes.fr/tel-01298046/document

Davaasambuu, B., \& Sato, T. (2014). A cost based handoff hysteresis scheme inwireless mobile relay node. In IEEE 80th Vehicular Technology Conference. doi:10.1109/NTCFall.2014.6965808

Davaasambuu, B., Semaganga, F., \& Sato, T. (2015). Adaptive handover hysteresis and call admission control for mobile relay nodes. International Journal of Computer Networks \& Communications, 7, 87-98. doi:10.5121/ijcnc.2015.7606

Davaasambuu, B., Yu, K., \& Sato, T. (2015). Self-optimization of handover parameters for long-term evolution with dual wireless mobile relay nodes. Future Internet, 7(2), 196-213.

Dimou, K., Min, W., Yu, Y., Kazmi, M., Larmo, A., Pettersson, J., . . Timner, Y. (2009). Handover within 3GPP LTE: Design principles and performance. In 2009 IEEE 70th Vehicular Technology Conference (VTC 2009-Fall), 1-9. doi:10.1109/ VETECF.2009.5378909

Ge, H., Wen, X., \& Zheng, W. (2009). A history-based handover prediction for LTE systems. In 1st international symposium on computer network and multimedia technology. Wuhan. doi:10.1109/CNMT.2009.5374706

Haider, F., Dianati, M., \& Tafazolli, R. (2011). A simulation based study of mobile femtocell assisted LTE networks. In IEEE Wireless Communications and Mobile Computing Conference. Istanbul: IEEE. doi:10.1109/IWCMC.2011.5982771

Holma, H., Toskala, A., \& Reunanen, J. (2016). LTE small cell optimization, 3GPP evolution to release 13. Chichester, UK: Wiley.

Isa, I. N., Baba, M. D., \& Yusof, A. L. (2015). Handover parameter optimization for self-organizing LTE networks. In 2015 IEEE Symposium on Computer Applications \& Industrial Electronics (ISCAIE). Langkawi. doi:10.1109/ISCAIE.2015.7298317

Jansen, T., Balan, I., \& Turk, J. (2010). Handover parameter optimization in LTE self-organizing networks. In 2010 IEEE $72 n d$ Vehicular Technology Conference - Fall. Otawa. doi:10.1109/NETECF.2010.5594245

Jengyueng, C., Chunchuan, Y., \& Yiting, M. (2015). A novel smart forwarding scheme in LTE-advanced networks. China Communications, 12(3), 120-131

Karimi, O. B., Liu, J., \& Wang, C. (2012). Seamless wireless connectivity for multimedia services in high speed trains. IEEE Journal on Selected Areas in Communications, 30(4), 729-739.

Krendzel, A. (2013). LTE-A mobile relay handling: Architecture aspects. 19th European Wireless Conference. Guildford: European Wireless. Retrieved from: https://ieeexplore.ieee.org/document/6582765/

Lee, C.-W., Chuang, M.-C., Chen, M. C., \& Sun, Y. (2014). Seamless handover for high-speed trains using femtocell-based multiple egress network interfaces. IEEE Transactions on Wireless Communications, 13(12), 6619-6628.

Lee, D.-W., Gil, G.-T., \& Kim, D.-H. (2010). A cost-based adaptive handover hysteresis scheme to minimize the handover failure rate in 3GPP LTE system. In EURASIP Journal on Wireless Communications and Networking, 2010. id.750173. doi: 10.1155/2010/750173 
Lee, H., Son, H., \& Lee, S. (2009). Semisoft handover gain analysis over OFDM-based broadband systems. IEEE Transactions on Vehicular Technology, 58, 1443-1453.

Lee, J. C., Cho, S.-P., \& Kim, H.-j. (2005). Position based handover control method. In LNCS 3481: International Conference on Computational Science and its Applications, (pp. 781-788). Berlin Heidelberg: Springer. doi:10.1007/11424826_83

Li, X.-W., \& Wang, J. (2013). The optimized method of reducing unnecessary handover in LTE system. In 2013 Third International Conference on Instrumentation, Measurement, Computer, Communication and Control. Shenyang. doi:10.1109/ IMCCC.2013.272

Lin, C.-C., Sandrasegaran, K., \& Reeves, S. (2012). Handover algorithm with joint processing in LTE-advanced. In 20129 th International Conference on Electrical Engineering/Electronics, Computer, Telecommunications and Information Technology. Phetchaburi. doi:10.1109/ECTICon.2012.6254240

Lin, C.-C., Sandrasegaran, K., \& Zhu, X. (2012). On the performance of capacity integrated CoMP handover algorithm in LTE-Advanced.In 2012 18th Asia-Pacific Conference on Communications (APCC). Jeju Island. doi:10.1109/ APCC. 2012.6388207

Link, C.-C., Sandrasegaran, K., Ramli, H., \& Basukala, R. (2011). Optimized performance evaluation of Ite hard handover algorithm with average RSRP constraint. International Journal of Wireless \& Mobile Networks (IJWMN). doi:10.5121/ ijwmn.2011.3201

Luan, L., Wu, M., Shen, J., Ye, J., \& He, X. (2012). Optimization of handover algorithms in LTE high-speed railway networks. International Journal of Digital Content Technology and its Applications, 6(5), 79-87.

Muñoz, P., Barco, R., \& Fortes, S. (2014). Conflict Resolution Between Load Balancing and Handover Optimization in LTE Networks. IEEE Communications Letters, 18(10), 1795-1798.

Rathod, N. (2013). Eficient handover scheme for LTE networks. Hyderabad: India: Indian Institute of Technology Hyderabad.

Sinclair, N., Harle, D., Glover, I., Irvine, J., \& Atkinson, R. (2013). An advanced SOM algorithm applied to handover management within LTE. IEEE Transactions on Vehicular Technology, 62(5), 1883-1894.

Su, D., Wen, X., Zhang, H., \& Zheng, W. (2010). A self-optimizing mobility management scheme based on cell id information in high velocity environment. In 2010 Second International Conference on Computer and Network Technology. Bangkok. doi:10.1109/ICCNT.2010.64

Sui, Y., Ren, Z., \& Sun, W. (2013). Performance study of fixed and moving relays for vehicular users with multi-cell handover under co-channel interference. In International Conference on Connected Vehicles and Expo (ICCVE). Las Vegas. doi:10.1109/ICCVE.2013.6799847

Sui, Y., Vihriälä, Y., Papadogiannis, A., Sternad, M., Yang, W., \& Svensson, T. (2013). Moving cells: A promising solution to boost performance for vehicular users. IEEE Communications Magazine, 51(6), 62-68.

Tao, M., Yuan, H., Hong, X., \& Zhang, J. (2016). SmartHO: mobility pattern recognition assisted intelligent handoff in wireless overlay networks. Soft Computing, 20(10), 4121-4130.

Tu, H.-M., Lin, J.-S., \& Chang, T.-S. (2012). Prediction-based handover schemes for relay-enhanced LTE-A systems. In 2012 IEEE Wireless Communications and Networking Conference (WCNC), Shanghai. doi:10.1109/WCNC.2012.6214293

Ulvan, A., Bestak, R., \& Ulvan, M. (2010). Handover scenario and procedure in LTE-based femtocell networks. In The Fourth International Conference on Mobile Ubiquitous Computing, Systems, Services and Technologies, Florence. doi:10.1109/ WMNC.2010.5678766

Wang, H.-L., Kao, S.-J., Hsiao, C.-Y., \& Chang, F.-M. (2014). A moving direction prediction-assisted handover scheme in LTE networks. EURASIP Journal on Wireless Communications and Networking, I, 190. doi:10.1186/1687-1499-2014-190

Wang, Q., Ren, G., \& Tu, J. (2011). A soft handover algorithm for TD-LTE system in high-speed railway scenario. In 2011 IEEE International Conference on Signal Processing, Communications and Computing (ICSPCC), 1-4. doi: 10.1109/ ICSPCC.2011.6061727

Wang, Y.-H., Huang, G.-R., \& Tung, Y.-C. (2014). A handover prediction mechanism based on LTE-A UE history information. In Computer, Information and Telecommunication Systems (CITS). doi: 10.1109/CITS.2014.6878975

Watanabe, Y., Matsunaga, Y., Kobayashi, K., Sugahara, H., \& Hamabe, K. (2011). Dynamic neighbor cell list management for handover optimization in LTE. In 2011 IEEE 73rd Vehicular Technology Conference (VTC Spring), Yokohama. doi: 10.1109/ VETECS.2011.5956456

Yang, F., Deng, H., Jiang, F., \& Deng, X. (2015). Handover optimization algorithm in LTE high-speed railway environment. Wireless Personal Communications, 84(2), 1577-1589.

Zhang, R., Wu, M., Zhang, Y., \& Luan, L. (2014). Alternative reference point based handover algorithm for LTE high-speed rail. Indonesian Journal of Electrical Engineering and Computer Science, 12(3), 2278-2284.

Zhao, H., Huang, R., Zhang, J., \& Fang, Y. (2011). Handoff for wireless networks with mobile relay stations. In 2011 IEEE Wireless Communications and Networking Conference, (pp. 826-831). Cancun. doi:10.1109/WCNC.2011.5779239

Zheng, N., \& Wigard, J. (2008). On the performance of integrator handover algorithm in LTE networks. In IEEE 68th Vehicular Technology Conference (VTC 2008-Fall), 1-5. doi:10.1109/NETECF.2008.296

Zheng, W., Wang, B., Zhang, H., Lu, Z., \& Wen, X. (2009). A novel self-optimizing handover mechanism for multi-service provisioning in LTE-advanced. In Research Challenges in Computer Science, International Conference on (ICRCCS), (pp. 221-224). Shanghai. doi:10.1109/ICRCCS.2009.64 
Trejo, E., \& Hernández, C. (2018).

\section{CURRICULUM VITAE}

Euler Trejo Narváez Electronics and Telecommunications Engineer (2004), student of the Master in Electronics and Telecommunications and member of the New Technologies in Telecommunications Research Group [GNTT] (Popayán, Colombia). He has over twelve years of experience in mobile networks, he has been worked as planning and optimization consultant in access networks (2G, 3G, and 4G) for Nokia Chile and Ericsson Ecuador, and in projects related with the design and optimization of mobile networks Claro in Colombia and Chile, and for Movistar in Chile and Ecuador / Ingeniero en el Electrónica y Telecomunicaciones (2004), estudiante de la Maestría en Electrónica y Telecomunicaciones y miembro del Grupo de investigación Nuevas Tecnologías en Telecomunicaciones [GNTT] de la Universidad del Cauca (Popayán, Colombia). Cuenta con doce años de experiencia laboral en redes móviles; se ha desempeñado como consultor de planeación y optimización de red de acceso (2G, 3G y 4G) para Nokia Chile y Ericsson Ecuador; y ha participado en proyectos de diseño y optimización para redes de Claro en Colombia y Chile, y Movistar en Chile y Ecuador.

Claudia Milena Hernández Electronics and Telecommunications Engineer (2004) and MSc. in Electronics and Telecommunications (2011) from the Universidad del Cauca (Popayán, Colombia), where she is also an active member of the New Technologies in Telecommunications Research Group [GNTT] and of the Radio and Wireless Group [Grial]. She has been an associated professor from 2005 in the telecommunications department. Her main teaching areas are focused on the mobile and wireless communications / Ingeniera en el Electrónica y Telecomunicaciones (2004) y Magister en Electrónica y Telecomunicaciones (2011) de la Universidad del Cauca (Popayán, Colombia), entidad donde además es miembro del grupo de investigación Nuevas Tecnologías en Telecomunicaciones [GNTT] y del Grupo de Radio en Inalámbricas [Grial] y docente, desde 2005, del departamento de Telecomunicaciones. Ella orienta sus labores de docencia e investigación en las áreas de comunicaciones móviles e inalámbricas. 